\title{
PANDANGAN HAKIM TERHADAP KEADAAN MEMAKSA
}

\author{
Suhandi Cahaya ${ }^{1}$
}

\begin{abstract}
Abstrak
The terminology of enforce situation in criminal law known as overmacht, whereas in civil law terminology of enforce situation known as force majeure. A contention on law that the only sources of law is the act and outside of the act are no law, now is being discarded. A judge has an authority to create their own rules by finding new legal norms or by interpreting law, which related to cases before him/her.
\end{abstract}

Keyword: overmacht, force majeure, code penal

\begin{abstract}
Abstrak
Keadaan Memaksa dalam hukum pidana dikenal dengan sebutan overmacht sedangkan keadaan memaksa dalam ruang lingkup hukum perdata dikenal dengan sebutan force majeure. Anggapan yang menyatakan bahwa sumber hukum satu-satunya adalah undang-undang dan di luar undang-undang tiada hukum, ternyata pada saat sekarang telah ditinggalkan orang. Hakim dapat membuat peraturan sendiri dengan jalan menemukan norma-norma hukum yang baru, ataupun dengan melakukan penafsiran hukum yang berhubungan dengan kasus yang diadilinya.
\end{abstract}

Kata kunci: overmacht, force majeure, hukum pidana

\section{Latar Belakang}

Pengertian keadaan memaksa hingga sekarang belum ada kesatuan pendapat. Ada pendapat yang mengatakan daya paksa ini sebagai alasan pembenar dan ada pula yang mengatakan bahwa keadaan memaksa ini termasuk alasan pemaaf. Di samping itu ada pula pendapat ketiga, yaitu yang mengatakan bahwa keadaan memaksa itu mungkin ada alasan pembenar dan mungkin pula alasan pemaaf. Keadaan memaksa menjadi fenomena yang terdapat di dalam konsep ${ }^{2}$ dan norma ${ }^{3}$ hukum baik di bidang Hukum Pidana ${ }^{4}$ disebut overmacht maupun di bidang Hukum Perdata ${ }^{5}$ disebut force majeure.

1 Penulis adalah Sta Pengajar pada Fakultas Hukum Universitas Jayabaya. Alamat kontak: suhandicahaya@yahoo.com.

${ }^{2}$ H. Hadari Nawawi dan Mimi Martini, "Penelitian Terapan", (Yogyakarta: Penerbit Gadjah Mada University Press, 1994), hal. 240. Konsep pada dasarnya berarti gagasan atau rancangan mengenai sesuatu yang telah ada di dalam pikiran. Konsep merupakan suatu gambaran mental dalam bentuk pendapat, pengertian atau gagasan umum mengenai sesuatu 
Aspek keadaan memaksa di bidang Hukum Pidana yang lebih dikenal dengan sebutan overmacht. Istilah ini selanjutnya akan dipakai di dalam disertasi ini. Menurut Hazewinkel Suringa, ${ }^{6}$ antara lain menyatakan sebagai berikut:

Wat overmacht is waarom zij straffeloosheid meebrengt en of deze laatste het feit zelf of de dader betreft, blijft in het duister.

Terjemahan bebas:

Apa sebenarnya overmacht itu, apa sebabnya ia telah membuat sesuatu hukuman menjadi tidak dapat dijatuhkan, dan apakah yang dimaksudkan terakhir ini berkenaan dengan perbuatannya atau berkenaan dengan pelakunya, adalah tetap tidak jelas.

Overmacht terdapat di dalam Pasal 48 Kitab Undang-undang Hukum Pidana yang rumusannya adalah sebagai berikut:

Niet strafbaar is hij die een feit begaat waartoe hij door overmacht is gedrongen.

Terjemahan bebas:

Tidaklah dapat dihukum barangsiapa telah melakukan sesuatu perbuatan di bawah pengaruh dari suatu daya paksa.

Dalam bahasa Inggrisnya:

berupa obyek, proses, peristiwa, kejadian dan lain-lain, baik yang berdiri sendiri maupun dalam hubungannya satu dengan yang lain.

${ }^{3}$ Wirjono Prodjodikoro, "Asas-asas Hukum Pidana di Indonesia", (Bandung: Penerbit PT. Eresco, 1989), hal. 12. Norma adalah suatu larangan atau suruhan (norma).

${ }^{4}$ C.S.T. Kansil dan Christine S.T. Kausil, "Pokok-Pokok Hukum Pidana: Antar Pidana Untuk Tiap Orang", (Jakarta: Penerbit, PT. Pradnya Paramita, 2004), hal. 1 menyebutkan hukum pidana ialah hukum yang mengatur tentang pelanggaran-pelanggaran dan kejahatankejahatan terhadap kepentingan umum perbuatan mana diancam dengan hukum yang merupakan suatu penderitaan atau siksaan.

5 Yan Pramadya Puspa, "Kamus Hukum", edisi Lengkap Bahasa Belanda, Indonesia Inggris, (Semarang: Penerbit, CV. Aneka Semarang Indonesia, 1977), hal. 450, Hukum Perdata adalah hukum yang mengatur hubungan antar orang termasuk badan hukum mengatur pula hak-hak dam kewajiban mereka atas kebendaan.

${ }^{6}$ Hazewinkel Suringa, "Inleiding”, hal. 156, lihat pula PAF Lamintang, "Dasar-Dasar Hukum Pidana Indonesia”, (1997), hal. 427. 
Not punishable shall be the person who commits an act to which he is compelled by force majeure. ${ }^{7}$

Keadaan Memaksa dalam hukum pidana dikenal dengan sebutan overmacht sedangkan keadaan memaksa dalam ruang lingkup hukum perdata dikenal dengan sebutan force majeure.

Baik overmacht (seseorang yang melakukan tindak pidana seperti yang terdapat pada Pasal 48 KUHP) maupun force majeure (seseorang atau badan hukum yang tidak dapat memenuhi prestasinya seperti yang terdapat di dalam Pasal 1244 B.W. dan Pasal 1245 B.W.) mempunyai kesamaan di dalam norma hukumnya yaitu suatu keadaan di mana pelaku/dader melakukan suatu perbuatan karena dalam keadaan yang benar-benar terpaksa. Overmacht adalah suatu keadaan ketika seseorang yang melakukan perbuatan karena terpaksa oleh suatu kekuasaan yang tak dapat dihindarinya. Kata terpaksa di sini haruslah diartikan baik paksaan batin maupun paksaan lahir, rohani ataupun jasmani. Kekuasaan yang tidak dapat dihindarkan ialah suatu kekuasaan yang berlebih, kekuasaan yang pada umumnya tidak dapat dilawan, jadi kesimpulannya overmacht adalah adanya kekuasaan dari pihak lain atau pihak luar terhadap si pelaku sehingga si pelaku tidak dapat melawan atau menghindari dari kekuatan yang lebih besar tersebut, oleh karena itu apa yang dilakukan oleh seseorang karena dirinya dalam keadaan terpaksa oleh kekuatan atau kekuasaan yang lebih besar maka ia tidak dapat dihukum.

Hal ini berlainan dengan force majeure dalam hukum perdata. Force majeure adalah suatu keadaan memaksa di mana seorang debitur tidak dapat melaksanakan prestasinya karena adanya keadaan atau peristiwa yang tidak terduga pada saat dibuatnya kontrak. Keadaan atau peristiwa tersebut tidak dapat dipertanggungjawabkan kepada debitur, sementara debitur tidak dalam keadaan beretikat buruk. Jadi kesimpulannya di dalam overmacht si pelaku tidak dapat menghindari diri oleh karena ada kekuatan dari pihak luar yang lebih kuat yang menguasainya sedangkan di dalam force majeure sangat jelas adanya pengaruh alam atau pihak lain terhadap prestasi yang mesti dilakukan oleh debitur.

Pandangan yang bersumber dari pendapat hakim terhadap force majeure dalam berbagai putusan Mahkamah Agung Republik Indonesia tidak ada yang sama antara putusan yang satu dengan putusan lainnya, dan pertimbangan hukum yang menjadi standar (ukuran) bagi hakim tersebut dalam menjatuhkan putusan tentang force majeure.

Seorang hakim haruslah menciptakan hukum dan membuat standar hukum (judge made law) dan seorang hakim tidak hanya menafsirkan hukum

${ }^{7}$ Penal Code of Indonesia, edited by: Directorate General of Law and Legislation Ministry of Justice, hal. 20. 
atau undang-undang, ${ }^{8}$ doktrin Sens-clair (la doctrine du sensclair) menyebutkan bahwa penemuan hukum oleh hakim hanya diperlukan apabila:

1. peraturannya belum ada untuk suatu kasus in konkreto; dan

2. peraturannya sudah ada tetapi belum jelas. ${ }^{9}$

Anggapan yang menyatakan bahwa sumber hukum satu-satunya adalah undang-undang dan di luar undang-undang tiada hukum, ternyata pada saat sekarang telah ditinggalkan orang. Anggapan itu mempunyai kelemahankelemahan, di antaranya banyak perkara yang memerlukan penerapan hukum, tetapi normanya tidak diatur, tidak lengkap, dan tidak sempurna memberikan aturan-aturan untuk perkara yang dihadapi oleh hakim tersebut, akibat dari keadaan seperti itu akan terjadi kevakuman hukum dalam masyarakat.

Undang-undang tidak selamanya mampu memenuhi segala sesuatu yang menyangkut kebutuhan hukum dalam masyarakat, oleh karena itu, wajar timbul pandangan yang mengatakan bahwa di luar undang-undang masih banyak kebutuhan pembentukan hukum yang lain sesuai dengan perkembangan masyarakat. Dalam hal ini kebutuhan pembentukan hukum, di samping kebiasaan-kebiasaan yang ada dalam masyarakat, dapat pula dilakukan oleh hakim.

Ketidakmampuan undang-undang mengatur segala peristiwa hukum yang ada dalam masyarakat, maka pada waktu tugas hakim memberikan suatu keputusan yang tidak langsung berdasarkan atas suatu peraturan. Hakim dapat membuat peraturan sendiri dengan jalan menemukan norma-norma hukum yang baru, ataupun dengan melakukan penafsiran hukum yang berhubungan dengan kasus yang diadilinya. Apabila keputusan hakim yang diambil berdasarkan hukum yang ditemukan sendiri itu diikuti atau dijadikan dasar keputusan bagi hakim yang lain, maka keputusan hakim yang terdahulu tadi telah menjadi sumber hukum yurisprudensi.

\section{Identifikasi Masalah}

Keadaan memaksa (overmacht dalam perkara pidana dan force majeure dalam perkara perdata) mempunyai hubungan bentuk. Meskipun demikian suatu peristiwa untuk dapat dikatakan sebagai keadaan memaksa tidaklah

\footnotetext{
${ }^{8}$ Lihat Pasal 22 Algemene Bepalingen van Wetgeving voor Indonesia dan Pasal 14 ayat (1) Undang-undang No.14 tahun 1970 yang menegaskan bahwa Pengadilan tidak boleh menolak memeriksa dan menggali suatu perkara yang diajukan dengan dalih bahwa hukum tidak atau kurang jelas, melainkan wajib untuk memeriksa dan mengadilinya. Lihat juga Sunarjati Hartono, "Hukum Ekonomi Pembangunan Indonesia", (1988) hal. 8, pendapat Von Savigny, yang mengatakan bahwa hukum itu tidak dibuat, akan tetapi timbul bersama-sama dengan masyarakat yang bersangkutan (DAS RECHT WIRD NICHT GEMACHT, EST IST AND WIRD MIT DEM VOLKE).
}

9 Achmad Ali, "Menguak Tabir Hukum, Suatu Kajian Filosofis dan Sosiologis", (Jakarta: Gunung Agung, 2002), hal. 145. 
mudah. Dalam hal ini hakim mempunyai peranan sentral dalam memutuskan apakah suatu peristiwa dapat dikatakan sebagai keadaan memaksa.

Peristiwa hukum dalam era globalisasi ini tidak dapat lagi dibatasi oleh yurisprudensi hukum, misalnya dalam perikatan yang bersifat internasional maupun tindak pidana transnasional. Dalam kaitan ini keadaan memaksa menjadi isu yang penting ketika hal tersebut menyangkut berbagai yurisprudensi hukum dari para subyek hukum yang terlibat di dalamnya. Oleh karena itu perlu diperoleh kejelasan bagaimana system hukum utama, yaitu Civil Law dan Common Law mengartikan overmacht dan force majeure, sehingga bila terjadi suatu peristiwa hukum yang dapat dikategorikan sebagai keadaan memaksa akan diperoleh keputusan yang adil, pasti dan bermanfaat bagi para pihak.

\section{Permasalahan}

Penelitian ini difokuskan kepada bagaimana pandangan hakim terhadap overmacht dan force majeure, dengan studi kasus Mahkamah Agung di Republik Indonesia, Supreme Court di Singapore, Supreme Court di Melbourne mengenai apa kriteria hakim di dalam menentukan overmacht dan force majeure di lingkungan hukum pidana maupun hukum perdata. Lingkup penelitian diarahkan pada permasalahan:

1. bagaimana pertimbangan hakim dari sistem Civil Law dibandingkan dengan sistem Common Law dalam menjatuhkan putusan yang berhubungan dengan keadaan memaksa, baik dalam perkara pidana (overmacht) dan perkara perdata (force majeure)?; dan

2. bagaimana persamaan dan perbedaan pengertian overmacht dan force majeure tersebut yang dapat ditarik dari putusan hakim dari dua sistem hukum yang berbeda tersebut?

\section{Tujuan dan Kegunaan Penelitian}

Sasaran penelitian ini difokuskan pandangan hakim terhadap overmacht dan force majeure sesuai dengan perkembangan ilmu pengetahuan dan praktek penerapan hukumnya. Maksud penelitian mengenai apa overmacht dan force majeure itu sendiri, bagaimana pandangan hakim terhadap keadaan memaksa baik ditinjau dari sudut hukum pidana maupun dari sudut hukum perdata. Tujuan penelitian adalah:

1. untuk mengetahui dan memperoleh pemahaman perkembangan hukum tentang overmacht maupun force majeure; dan

2. untuk mengetahui dan memperoleh pengetahuan tentang alasan pertimbangan hukum yang digunakan oleh hakim dalam menjatuhkan putusan tentang keadaan memaksa baik dalam overmacht maupun force majeure. 
Sedangkan kegunaan penelitian adalah:

1. menambah wawasan dan hasil pemikiran tentang berbagai pandangan hukum tentang overmacht dan force majeure yang diharapkan sebagai bahan menambah daftar perpustakaan ilmu hukum baik pidana maupun perdata;

2. memberikan bahan masukan terhadap penyelenggara penegak hukum untuk penyelesaian konflik hukum yang mengandung tentang overmacht dan force majeure di Mahkamah Agung Republik Indonesia dan segenap jajarannya; dan

3. memperluas pengertian tentang overmacht dan force majeure baik dalam bidang hukum pidana maupun perdata.

\section{Kerangka Teoritis dan Konseptual}

Hukum pidana adalah peraturan hukum mengenai pidana. Kata "pidana" berarti hal yang "dipidanakan", yaitu yang oleh instansi yang berkuasa dilimpahkan kepada seorang oknum sebagai hal yang tidak enak dirasakannya dan juga hal yang tidak sehari-hari dialaminya. ${ }^{10}$ Bandingkan dengan pendapat Bryan A. Garner yang menyatakan bahwa:

Criminal law is the body of law defining offenses against the community at large, regulating how suspects are investigated, charged, and tried, and establishing punishments for convicted offenders. ${ }^{11}$

Menurut Memorie van Toelichting mengenai pembentukan Pasal 48 KUHP, ketentuan itu disebut sebagai suatu "uitwendige oorzaak van ontoerekenbaarheid"12 atau sebagai suatu "penyebab yang datang dari luar yang membuat sesuatu perbuatan itu menjadi tidak dapat dipertanggungjawabkan kepada pelakunya". Hakikat overmacht dirumuskan sebagai "elke kracht, elke dwang, elke drang, waaraann men geen weerstand kanhbieden"13 atau setiap kekuatan, setiap paksaan, setiap tekanan, di mana terhadap kekuatan, paksaan atau tekanan tersebut orang tidak dapat memberikan perlawanan.

${ }^{10}$ Wirjono Prodjodikoro, "Asas-asas Hukum Pidana di Indonesia", (Bandung: Penerbit PT. Eresco, 1989), hal. 1.

${ }^{11}$ Bryan A. Garner, "Black's Law Dictionary", seventh edition (ST. Paul, Minn, West Group, 1999), hal. 295.

${ }^{12}$ Hazewinkel-Suringa, Op. Cit.

${ }^{13}$ Pompe, Handboek, hal. 128; Hazewinkel-Suringa, Ibid. 
Berdasarkan rumusan mengenai overmacht yang terdapat di dalam Memorie van Toelichting di atas, dalam perkembangan selanjutnya pembentuk undang-undang telah mengakui tentang adanya tiga macam peristiwa pokok adalah:

1. Peristiwa-peristiwa di mana terdapat pemaksaan secara phisik;

2. Peristiwa-peristiwa di mana terdapat pemaksaan secara psikis; dan

3. Peristiwa - peristiwa di mana terdapat suatu keadaan yang biasanya

4. disebut sebagai $N$ ot $h s t a n d,{ }^{14}$ noodtoestand ${ }^{15}$ atau sebagai etat de necessite, yaitu suatu keadaan di mana terdapat:

a. suatu pertentangan antara kewajiban hukum yang satu dengan kewajiban hukum yang lain;

b. suatu pertentangan antara suatu kewajiban hukum dengan suatu kepentingan hukum; dan

c. suatu pertentangan antara kepentingan hukum yang satu dengan kepentingan hukum yang lain. ${ }^{16}$

Negara-negara Common Law mengenal overmacht sama dengan self defense, dan self-defense adalah merupakan bagian dari defenses. Yang meliputi defenses adalah sebagai berikut:

1. Alibi (kesimpulan bahwa seseorang tidak mungkin menjalankan tindak pidana yang dituduhkan, karena sewaktu kejadian itu ia berada di tempat lain);

2. Compulsion (tekanan, paksaan, constraint);

3. Consent (izin);

4. Entrapment (penjebakan, memberi umpan agar seseorang yang dicurigai masuk ke dalam perangkap);

5. Execution of judgement or mandate (perintah pelaksanaan keputusan pengadilan, perampungan suatu dokumen: penandatanganan, pembubuhan materai, penyerahan);

6. Feeblemindedness;

7. Former conviction or acquittal (masalah yang menyangkut pembebasan dari suatu tanggungan);

8. Former jeopardy (satu perkara criminal yang dituduhkan dua kali);

9. Ignorance or mistake (tidak mengetahui fakta yang sebenarnya atau bukti perkara yang salah);

10. Infancy (orang di bawah umur);

11. Insanity or mental irresponsibility (ketidakwarasan mental);

12. Intoxication (pemabukan);

${ }^{14}$ Noyon-Langemeijer, "Het Wetboek I", hal. 247.

${ }^{15}$ Simons, "Leerboek I", hal. 279, dan seterusnya; van Hattum, "Hand-en leerboek I", hal. 347, dan seterusnya; van Bemmelen, "Ons Strafrecht I", hal. 183, dan seterusnya.

${ }^{16}$ Simons, Op. Cit., hal 279-281; M.A 27 Juli 1969 No. 117 K/Kr/1968 dalam Lamintang-Samosir, "Hukum Pidana Indonesia", hal. 29. 
Self-defense (mempertahankan diri dari serangan orang lain yang membahayakan hidupnya - overmacht/noodweer)

13. Statute of limitations (undang-undang yang dikeluarkan oleh badan legislative);

14. Unconsciousness (dengan tidak sadar);

15. Mistake (kesesatan);

16. Automatism (Gerakan otomatik/tidak terkontrol);

17. Disminished Responsibility.

Dalam Putusan Pengadilan Negeri Kraksaan, No.51/Pid/S/1985/ PN.Kraksaan, Jawa Timur tanggal 17 Desember 1985 atas nama Terdakwa Suwarno yang didakwa melanggar Pasal 359 KUHP ternyata di tingkat kasasi Mahkamah Agung Republik Indonesia dengan putusannya tanggal 17 Februari 1988 dalam perkara pidana No.624 K/Pid/1986, telah membebaskan terdakwa Suwarno dari dakwaan saudara Jaksa Penuntut Umum.

Bandingkan dengan putusan Mahkamah Agung nomor 1074 k/Pid/1992 tanggal 8 November 1994 yaitu notaris dipaksa untuk membuat akte menyimpang dari surat wasiat.

Pendapat J.E. Jonkers dikenal beberapa azas yang berlaku sangat luas dalam ilmu pengetahuan hukum pidana tetapi dalam beberapa hal telah ada yang dirumuskan terbatas dalam undang-undang:

1. alasan pembenar (rechtsvaardigingsgronden), yaitu menghapuskan sifat melawan hukumnya perbuatan, sehingga menjadi perbuatan yang benar;

2. alasan pemaaf (schulduitsluitingsgronden), yaitu menghapuskan sifat kesalahan dari terdakwa meskipun perbuatannya bersifat melawan hukum tetapi tidak pidana; dan

3. alasan penghapus penuntutan (onvervolgbaarheid), yaitu pernyataan tidak menuntut karena tidak dapat diterima oleh badan penuntut umum yang disebabkan konflik kepentingan dengan lebih mengutamakan kemanfaatannya untuk tidak menuntut. ${ }^{17}$

Menurut Vos Pasal 48 KUHP memberikan kelonggaran kepada hakim untuk meniadakan sifat melawan hukumnya perbuatan seseorang yang melanggar undang-undang yang tidak dipidana karena alasan penghapusan pidana. ${ }^{18}$ dan menurut J.E. Sahetappy, ${ }^{19}$ bahwa penghapusan pidana adalah termasuk alasan penghapus kesalahan umum yang tertulis ialah:

1. kemampuan bertanggungjawab (Pasal 44 KUHP);

2. daya paksa karena dorongan psikis (Pasal 48 KUHP);

3. pembelaan terpaksa melampaui batas (Pasal 49 ayat 2 KUHP); dan

${ }^{17}$ Bambang Poernomo, "Asas-asas Hukum Pidana”, Seksi Kepidanaan Fakultas Hukum Universitas Gajah Mada-Yogyakarta, (Penerbit: Ghalia Indonesia, 1992), hal. 57.

${ }^{18}$ Bambang Poernomo, Ibid., hal. 87.

19 Schaffmeister, N. Keijzer, Sutorius, editor penerjemahan oleh: J.E. Sahetapy, "Hukum Pidana", (Yogyakarta: Penerbit Liberty, 1995), hal. 152. 
4. kesesatan yang dapat dimaafkan mengenai kewenangan atas jasa mana suatu perintah jabatan diberikan (Pasal 51 ayat 2 KUHP).

termasuk alasan penghapus sifat melawan hukum, ialah:

1. daya paksa dalam arti keadaan darurat (Pasal 48 KUHP);

2. daya paksa dalam arti terpaksa memilih antara kewajiban-kewajiban yang bertentangan (Pasal 48 KUHP);

3. pembelaan terpaksa (Pasal 49 ayat $1 \mathrm{KUHP}$ );

4. peraturan perundang-undangan (Pasal $50 \mathrm{KUHP}$ ); dan

5. perintah jabatan (Pasal 51 ayat $1 \mathrm{KUHP}$ ).

Hal ini dapat dibuktikan dengan adanya putusan Mahkamah Agung Republik Indonesia dalam Kpts. Reg. No. 72 K/Kr/1970 tanggal 27 Mei 1972 (Yur. Ind. Mah. Agung III/1972) telah memberikan keputusan dengan menganut pandangan materiile wederechttelijkheid, yang memberikan pertimbangan hukum bahwa meskipun apa yang dituduhkan adalah suatu delik formil, namun hakim secara materiil harus memperhatikan juga adanya kemungkinan keadaan dari terdakwa atas dasar mana mereka tidak dapat dihukum (materiile wederechttelijkheid) sehingga terdakwa dilepas dari segala tuntutan hukum.

Lihat juga putusan Mahkamah Agung Republik Indonesia pada tahun 1956 pada perkara Reg. No. $138 \mathrm{~K} / \mathrm{Kr} / 1955$ tanggal 1 Desember 1956 (Kumpulan Keputusan Mahkamah Agung) yang membebaskan terdakwa karena tidak terdapatnya salah satu sifat/elemen kesalahan (schuld) sehingga tidak dipidana tanpa kesalahan. Duduk persoalannya adalah seorang perempuan telah diceraikan dengan thalaq gugur karena adanya pelanggaran taklik oleh Pengadilan Agama dan atas dasar perceraian itu lalu mengadakan perkawinan dengan laki-laki lain di hadapan seorang khotib, yang mengakibatkan ketiga orang itu dituntut Pasal 279 (1) ke-1e dan ke- $2^{20}$ dan Pasal 436 (1) KUHP. ${ }^{21}$ Terlepas dari sah atau tidak berdirinya Pengadilan Agama itu, oleh Mahkamah Agung dalam pertimbangannya menyatakan bahwa para terdakwa selayaknya percaya saja putusan perceraian itu, maka hal itu mengenai kekeliruan dari pihak penuntut kasasi I dan II (terdakwa) yang dapat dimaafkan "verschoonbare dwaling" dengan tidak terbukti ketika mereka melakukan perkawinannya mengetahui ada halangan dari perkawinan

\footnotetext{
${ }^{20}$ Pasal 279 ayat 1 ke-le: Dihukum penjara selama-lamanya lima tahun: Barangsiapa yang kawin sedang diketahuinya, bahwa perkawinannya yang sudah ada menjadi halangan yang sah baginya akan kawin lagi.

Ayat 2: kalau orang yang bersalah karena melakukan perbuatan yang diterangkan di 1e, menyembunyikan kepada pihak yang lain, bahwa perkawinannya yang sudah ada itu menjadi halangan yang sah akan kawin lagi dihukum penjara selama-lamanya 7 tahun.

${ }^{21}$ Pasal 436 Ayat 1: Barangsiapa menurut hukum yang berlaku bagi masing-masing pihak mempunyai kewenangan melangsungkan perkawinan seseorang, padahal diketahuinya bahwa perkawinan atau perkawinan-perkawinan orang itu yang telah ada menjadi halangan untuk itu berdasarkan undang-undang, diancam dengan pidana penjara paling lama tujuh tahun.
} 
terdahulu. Putusan Mahkamah Agung tersebut yang membebaskan para terdakwa karena kesalahannya dimaafkan "verschoonbare dwaling" karena perbuatan terdakwa tidak dapat diharapkan mengetahui telah melanggar undang-undang. Sebenarnya memperhatikan sikap batin terdakwa yang demikian itu, akan lebih tepat apabila diputuskan "dilepaskan dari segala tuntutan hukum" dengan dasar hukum karena terdakwa tidak dapat dihukum atau bukan sebagai kejahatan/pelanggaran, meskipun perbuatannya itu sendiri telah terbukti.

Dapat juga tidak dipidananya seseorang karena asas-asas hukum tak tertulis yang terdapat di dalam pandangan "materiile wederechttelijkheid". Pendapat Van Bemmelen penghapusan pidana berdasarkan pandangan yang materiile wederechttelijkheid itu dikenal sebagai "buiten wettelijke rechtvaardigingsgrond" yaitu keadaan tertentu dari perbuatan seseorang yang meniadakan sifat melawan hukumnya perbuatan yang terletak di luar undangundang. ${ }^{22}$

Keadaan memaksa secara khusus di dalam ruang lingkup hukum perdata adalah suatu keadaan dimana seorang debitur terhalang untuk melaksanakan prestasinya karena keadaan atau peristiwa yang tidak terduga pada saat dibuatnya kontrak, keadaan atau peristiwa tersebut tidak dapat dipertanggungjawabkan kepada si debitur, sementara si debitur tersebut tidak dalam keadaan beretikat buruk.

Dalam hal penegakan hukum ${ }^{23}$ yang menimbulkan kewajiban untuk membayar ganti rugi sebagaimana kedua pasal tersebut di atas? Ganti rugi merupakan akibat dari perbuatan melawan hukum ${ }^{24}$ atau wanprestasi ${ }^{25}$ dan

${ }^{22}$ Bambang Poernomo, Op. Cit., hal. 86.

${ }^{23}$ Penegakan hukum, haruslah meliputi keseluruhan komponen system hukum, baik yang menyangkut materi hukum (legal substance), struktur hukum (legal structure), maupun budaya hukum (legal culture), H.A.S Natabaya, "Penegakkan Supremasi Hukum", Majalah Hukum Nasional, Badan Pembinaan Hukum Nasional, Departemen Kehakiman \& Hak Asasi Manusia, nomor 1, Jakarta, 2001,hal 3, Lihat pula Suherman Toha, "The Enforcement of Law", is basic of sources to maintain order, for improvement of state, it is needed to have a concrete stages legal development which consists of law substance law aparatur and law culture, also can be understand threatness and weakness that effecting of law. In the other word, only with interdisiplinerily legal development and by all people support, supremary of law to be achieved, penegakkan hukum dan hak asasi manusia terwujudnya supremasi hukum, Majalah Hukum Nasional, Badan Pembinaan Hukum Nasional, Departemen Kehakiman \& Hak Asasi Manusia, nomor 2, Jakarta, 2001, hal. 167.

${ }^{24}$ Pasal 1365 B.W. menyebutkan: Tiap perbuatan melanggar hukum, yang membawa kerugian kepada orang lain, mewajibkan orang yang karena salahnya menimbulkan kerugian itu mengganti kerugian tersebut.

${ }^{25}$ Pasal 1243 B.W. menyebutkan: Penggantian biaya, rugi dan biaya karena tak dipenuhinya suatu perikatan haruslah mulai diwajibkan, apabila si berutang setelah dinyatakan lalai memenuhi perikatannya, tetap melalaikannya atau jika sesuatu yang harus dilakukan atau dibuatnya dalam tenggang waktu yang telah dilampaukannya. 
merupakan perwujudan dari asas hukum dan keadilan bagi negara seperti di negara-negara Common Law, yaitu diantaranya Singapore ${ }^{26}$ dan Australia yang menganut Common Law dan keadilan berdasarkan Almighty of God, seperti di negara-negara yang menganut Civil Law yang menyebutkan demi keadilan berdasarkan ke-Tuhanan yang Maha Esa seperti di Indonesia, ${ }^{27}$ yang terdapat dalam Pasal 4 ayat 1 Undang-undang nomor 4 tahun 2004 tentang Kekuasaan Kehakiman. $^{28}$

Pandangan hakim dalam memutuskan suatu perkara yang dikategorikan sebagai force majeure sangat penting dan menentukan. Sebab tidak ada satu putusan pengadilan yang telah mempunyai kekuatan hukum yang tetap dan pasti yang menguraikan secara tepat, rinci, serta akurat, dan benar mengenai suatu perkara yang gugatannya dikabulkan atau ditolak oleh Hakim berdasarkan suatu force majeure dengan 16 macam arti: ${ }^{29}$

1. karena sebab-sebab yang tidak terduga;

2. karena force majeure itu sendiri;

3. karena perbuatan itu dilarang;

4. force majeure yang objective;

5. force majeure yang subjective;

6. force majeure yang absolute;

7. force majeure yang relative;

8. force majeure yang temporer;

9. force majeure yang permanent;

10. force majeure karena ketidakmungkinan;

11. force majeure karena ketidakpraktisan;

12. force majeure karena frustrasi;

13. hardship;

14. irresistibility;

15. unforeseability; dan

16. externality.

Doktrin Sens-clair, menyebutkan bahwa penemuan hukum oleh hakim hanya diperlukan apabila:

${ }^{26}$ Lihat putusan dalam perkara divorce petition nomor 253 of 1996 tanggal 26 Februari 1996 tertulis In The High Court Of The Republic Of Singapore between Darwin Liman Indonesian Passport nomor 491531 (Petitioner) and Zhang Qing (m.w) (Indonesian passport nomor 491532 (Respondent).

27 Misahardi Wilamarta, "Hak Pemegang Saham Minoritas dalam Rangka Good Corporate Government", (Fakultas Hukum Universitas Indonesia, 2002), hal. 67.

${ }^{28}$ Pasal 4 ayat 1: Peradilan dilakukan "DEMI KEADILAN BERDASARKAN KETUHANAN YANG MAHA ESA".

${ }^{29}$ Munir Fuady, "Hukum Kontrak, Dari Sudut Pandang Hukum Bisnis", (Jakarta: PT. Citra Aditya Bakti, 1999), hal. 114. 
a. peraturannya belum ada untuk suatu kasus in konkreto; dan

b. peraturannya sudah ada tetapi belum jelas. ${ }^{30}$

Hal senada juga disampaikan oleh Julius Stone yang menyebutkan yurisprudensi adalah:

It is the lawyer's examination of the preceipts, ideals and techniques of the law in the light derived from present knowledge in disciplines other than the law. ${ }^{31}$

Sedangkan Yurisprudensi menurut Achmad Ali adalah sebagai berikut:

Yurisprudensi (biasa) yaitu seluruh putusan Pengadilan yang telah memiliki kekuatan pasti (inkracht van gewisjsde) yang terdiri dari:

a) putusan perdamaian (dalam perkara perdata);

b) putusan Pengadilan Negeri yang tidak dibanding;

c) putusan Pengadilan Tinggi yang tidak dikasasi; dan

d) seluruh putusan Mahkamah Agung.

Yurisprudensi tetap (vaste jurisprudentie) yaitu putusan hakim yang selalu diikuti oleh hakim lain dalam perkara sejenis. ${ }^{32}$

Dalam penulisan disertasi ini peneliti menggunakan Kerangka Teoritis berupa Grand Theory oleh Michel Van Kerckhove, yaitu teori yang diambil langsung dari perpustakaan seperti yang terdapat di dalam doktrin Sens Clair dan berpaham dalam hukum alam sebagaimana yang dianut oleh Aristoteles yang menjelaskan sebagai berikut:

Laws are something different from what regulates and expresses the form of the constitution; it is their function to direct the conduct of the magistrate in the execution of his office and the punishment of offenders.

\section{Terjemahan bebas:}

Hukum adalah sesuatu yang berbeda daripada sekedar mengatur dan mengekspresikan bentuk dari konstitusi; hukum berfungsi

${ }^{30}$ Achmad Ali, Op. Cit., hal. 145.

${ }^{31}$ Stone, JR, "Legal System and Lawyer's Reasoning", p. 16, Dikutip dari buku Hari Chamad, "Modern Jurisprudence International Law Box Service", (Kuala Lumpur: tanpa penerbit, 1994), hal. 1.

${ }^{32}$ Achmad Ali, Op. Cit., hal. 125. 
untuk mengatur tingkah laku para hakim dan putusannya di pengadilan dan untuk menjatuhkan hukuman terhadap pelanggar. ${ }^{33}$

dan Middle Range Theory yaitu teori yang sudah masuk di dalam konsep. Kerangka teoritis adalah merupakan strategi dan pendekatan untuk memecahkan masalah sedangkan kerangka konseptual adalah suatu kerangka konsepsi dari peneliti yang menjanjikan hubungan antara variable yang diperkirakan akan terjadi dan didapatkan dari hasil penjabaran tinjauan pustaka. Pada tinjauan pustaka diungkapkan materi yang berkaitan dengan masalah penelitian. Berdasarkan uraian kepustakaan tersebut, maka peneliti memilih dan menggunakan teori atau konsep yang paling sesuai dan berkaitan untuk digunakan dalam pemecahan masalah penelitian. Dengan demikian, kerangka konseptual adalah bagian yang mengungkapkan strategi dan pendekatan peneliti untuk memecahkan masalah. Dalam menggambarkan uraian konsepsi pada kerangka pemikiran tersebut, peneliti perlu menjelaskan variable dan hubungan antara yang terjadi untuk menjawab masalah penelitian.

\section{Tujuan Kerangka Konseptual}

Kerangka konseptual sebaiknya dipisahkan dari uraian tinjauan pustaka, namun tetap berada dalam bab yang sama, karena kerangka konseptual ini merupakan hasil identifikasi yang sistematis dan analisis yang kritis dari peneliti sendiri berdasarkan hasil studi kepustakaannya dan pengamatan awal dari peneliti terhadap masalah. Namun, untuk laporan penelitian (selain skripsi, tesis dan disertasi), kerangka konseptual dapat digabungkan dengan uraian tinjauan pustaka. Tujuan kerangka konseptual adalah untuk:

a. memberikan arah strategi dan pendekatan peneliti untuk memecahkan masalah. Dengan adanya kerangka konseptual maka peneliti lebih mudah untuk merencanakan dan menyusun langkah berikutnya, dan pembaca dapat mengetahui logika pemikiran yang digunakan oleh peneliti dalam memecahkan masalah;

b. menggambarkan secara menyeluruh konsep yang digunakan dalam penelitian, dan sekaligus dapat menyajikan hubungan antara variable atau factor yang digunakan oleh peneliti; dan

c. menghindari kesalahan yang pernah dilakukan oleh peneliti sebelumnya dan dapat mengambil manfaat dari pengalaman mereka.

\section{Perumusan Kerangka Penelitian}

Kerangka pemikiran dimulai dengan uraian yang menggambarkan konsep yang telah dipilih dan ditentukan oleh peneliti, dan selanjutnya uraian tersebut sebaiknya diformulasikan dan dirumuskan dalam bentuk

${ }^{33}$ Ibid., hal. 25. 
model, yaitu: model skematik/bagan, model input-proses-output, atau model simbolik/matematik. Dengan demikian, kerangka konseptual perlu memenuhi beberapa kriteria: 1. dimulai dengan uraian yang menggambarkan konsep, variable serta hubungan antara konsep, dan variable tersebut; dan 2. diakhiri dengan rumusan berbentuk: model skematik/bagan, model input-proses-output, atau model simbolik/ matematik. $^{34}$

Teori yang digunakan di dalam penelitian disertasi ini adalah keadaan darurat tidak mengenal larangan atau boleh dikatakan adanya alasan pemaaf atau alasan pembenar baik dalam ruang lingkup hukum pidana maupun ruang lingkup hukum perdata dengan menggunakan teori kontrak sebab force majeure sebagaimana lazimnya dimasukkan dalam klausul/salah satu pasal di kontrak tersebut.

Hukum pidana adalah bagian dari keseluruhan hukum yang berlaku di suatu negara, yang mengadakan dasar-dasar dan aturan-aturan untuk:

a. menentukan perbuatan-perbuatan mana yang tidak boleh dilakukan, yang dilarang, dengan disertai ancaman atau sanksi yang berupa pidana tertentu bagi barang siapa melanggar larangan tersebut;

b. menentukan kapan dan dalam hal-hal apa kepada mereka yang telah melanggar larangan-larangan itu dapat dikenakan atau dijatuhkan pidana sebagaimana yang telah diancamkan; dan

c. menentukan dengan cara bagaimana pengenaan pidana itu dapat dilaksanakan apabila ada orang yang disangka telah melanggar larangan tersebut. ${ }^{35}$

Pompe menambahkan, hukum pidana adalah semua aturan-aturan hukum yang menentukan terhadap perbuatan-perbuatan apa seharusnya dijatuhi pidana. ${ }^{36}$ Bandingkan pendapat dari Perkins dalam Elements of Police Science, Chicago 1942, menyebutkan sebagai berikut:

Criminal law often used to include all that is involved in the administration of criminal justice. ${ }^{37}$

Hal senada juga disampaikan oleh Simons almarhum (Utrecht) dalam bukunya Leerboek Nederlands Strafrecht 1937 yang memberikan pendapat sebagai berikut: hal. 21.

${ }^{34}$ Azril Azahari, "Karya Tulis Ilmiah", (Jakarta: Penerbit Universitas Trisakti, 1998),

${ }^{35}$ Moeljatno, “Asas-Asas Hukum Pidana”, (Jakarta: Penerbit Rineka Cipta, 2002), hal. 1.

\footnotetext{
${ }^{36}$ Ibid., hal. 7.

${ }^{37}$ Ibid.
} 
Hukum pidana adalah kesemuanya perintah-perintah dan larangan-larangan yang diadakan oleh negara dan yang diancam dengan suatu nestapa (pidana) barangsiapa yang tidak mentaatinya, kesemuanya aturan-aturan yang menentukan syarat-syarat bagi akibat hukum itu dan kesemuanya aturan-aturan untuk mengadakan (menjatuhi) dan menjalankan pidana tersebut. ${ }^{38}$

Dan lagi pendapat Van Hamel dalam bukunya Inlending Studie Ned Strafrecht 1927, yang demikian isinya:

Hukum pidana adalah semua dasar-dasar dan aturan-aturan yang dianut oleh suatu negara dalam menyelenggarakan ketertiban hukum (rechtsorde) yaitu dengan melarang apa yang bertentangan dengan hukum dan mengenakan suatu nestapa kepada yang melanggar larangan-larangan tersebut. ${ }^{39}$

Bandingkan dengan pendapat Joel Samaha yang menyebutkan Criminal Law adalah sebagai berikut:

Criminal law is the study of the ordinary phenomena of life under extraordinary circumstances, criminal law consists of the power and limits of government authority to define, prohibit, grade, and punish socially harmful behavior, criminal law is distinguished from all other law because it carries with it the moral condemnation of the whole community. ${ }^{40}$

Dalam teori hukum pidana biasanya alasan-alasan yang menghapuskan pidana ini dibeda-bedakan menjadi:

a. alasan pembenar yaitu alasan yang menghapuskan sifat melawan hukumnya perbuatan, sehingga apa yang dilakukan oleh terdakwa lalu menjadi perbuatan yang patut dan benar;

b. alasan pemaaf yaitu alasan yang menghapuskan kesalahan terdakwa. Perbuatan yang dilakukan oleh terdakwa tetap bersifat melawan hukum jadi tetap merupakan perbuatan pidana, tetapi dia tidak dipidana, karena tidak ada kesalahan; dan

c. alasan penghapus penuntutan di sini soalnya bukan ada alasan pembenar maupun alasan pemaaf, jadi tidak ada pikiran mengenai sifatnya perbuatan maupun sifatnya orang yang melakukan perbuatan, tetapi pemerintah menganggap bahwa atas dasar utilitas atau kemanfaatannya kepada masyarakat, sebaiknya tidak diadakan penuntutan.

${ }^{38}$ Ibid., hal. 8.

${ }^{39} \mathrm{Ibid}$.

40 Joel Samaha, "Criminal Law", fifth edition, (St. Paul, MN 55164-0526 By West Publishing Company, 1993), hal. 2. 
Biasanya dalam Titel 3 Buku Pertama yang dipandang orang sebagai alasan pembenar adalah: Pasal-Pasal 49 (1) KUHP mengenai pembelaan terpaksa (noodweer), Pasal 50 KUHP mengenai melaksanakan ketentuan undang-undang, Pasal 51 (1) KUHP tentang melaksanakan perintah dari pihak atasan. Sedangkan yang dianggap sebagai alasan pemaaf adalah Pasal 49 (2) KUHP tentang pembelaan yang melampaui batas, Pasal 51 (2) KUHP (alasan penghapus), penuntutan pidana tentang perintah jabatan yang tanpa wenang.

Pasal 48 KUHP dan Pasal 49 KUHP termasuk kedalam alasan pemaaf (schulduitschemtiggronden) yaitu menghapus sifat kesalahan dari terdakwa meskipun perbuatannya bersifat melawan hukum tetapi tidak dipidana.

Pendapat Roscoe Pound bahwa: Ada tiga sifat yang dimulai dari semua system hukum biasa yang lain: 1. supremasi Hukum; 2. hukum kasus dan sesuatu yang dapat dijadikan teladan; dan 3. prosedur yang suka menghasilkan debat.

Definisi hukum dari Roscoe Pound menunjuk jelas pandangannya yang realistis dan sosiologis yang ditekankan oleh Roscoe Pound dalam definisi hukum adalah bahwa hukum merupakan realitas social, hal ini sejalan dengan yang dikemukakan oleh Satjipto Raharjo bahwa hukum harus dipandang sebagai pranata sosial ${ }^{41}$ oleh karena itu barangsiapa yang tidak dapat menepati janji dalam suatu kontrak maka akan disebut dengan cidera janji sebagaimana yang terdapat dalam Pasal 1243 B.W. oleh karena itu apa yang telah tertulis di dalam kontrak merupakan suatu perjanjian yang tertulis sebagaimana yang dikemukakan dalam Pasal 1320 B.W. dan kontrak menurut pengertian dari "Business Law" masih diperlukan perubahan hukum ikatan kontrak sebagai berikut:

Suatu kontrak ialah suatu pasang perjanjian yang untuk pelanggarannya hukum memberi jalan keluarnya atau pelaksanaannya hukum dengan cara yang sama mengakuinya sebagai kewajiban.

Ronald A. Anderson menerangkan:

Umumnya kontrak adalah pertukaran janji-janji atau persetujuan antara dua orang atau lebih, yang menghasilkan suatu kewajiban yang harus dipenuhi atau yang tidak boleh dilakukan, suatu kewajiban yang diakui atau diberlakukan oleh hukum.

Sementara itu pendapat Catherine Tan Swee Kian, sebagai berikut:

${ }^{41}$ Achmad Ali, Op. Cit., hal. 3. Bandingkan dengan pendapat Satjipto Rahardjo barubaru ini, juga menunjukkan kerancuan hukum kita, sampai beliau berkesimpulan, bahwa khusus tentang lembaga Pengadilan tidak cukup dengan pembenahan kecil-kecilan, akan tetapi dengan perombakan yang menyeluruh, yang dalam istilah beliau dengan "general Check up", seperti istilah dalam ilmu kedokteran, yaitu pemeriksaan seksama secara menyeluruh kondisi kesehatan seorang pasien. 
Intisari suatu kontrak ialah adanya suatu kesepakatan. Masing-masing pihak pertama-tama harus mencapai satu kesepakatan. Untuk mendapatkan suatu kesepakatan, harus ada suatu usulan dari satu pihak yang akan diterima oleh pihak kedua.

Definisi kontrak menurut Henry R.Cheeseman sebagai berikut:

Kontrak adalah kesepakatan yang diberlakukan oleh suatu pengadilan hukum atau badan serupa atau definisi yang sederhana yang diterima secara luas disediakan oleh pernyataan kembali (ke 2) dari kesepakatan. Kontrak adalah suatu janji atau seperangkat janji yang oleh hukum diberikan cara pemulihan bila dilanggar atau dengan pelaksanaan sesuatu yang oleh hukum dianggap sebagai suatu kewajiban.

Ketentuan hukum Pasal 1320 B.W. ${ }^{42}$ ada 4 element dari suatu kontrak:

1) sepakat mereka yang mengikatkan dirinya;

2) kecakapan untuk membuat suatu perikatan;

3) suatu hal tertentu; dan

4) tujuan yang dibolehkan.

Suatu perjanjian haruslah dibuat secara sah dan perjanjian ini berlaku sebagai undang-undang bagi mereka yang membuatnya coba dilihat Pasal 1338 B.W, demikian isinya:

Semua perjanjian yang dibuat secara sah berlaku sebagai undang-undang bagi mereka yang membuatnya.

Suatu perjanjian tidak dapat ditarik kembali selain dengan sepakat kedua belah pihak atau karena alasan-alasan yang oleh undang-undang dinyatakan cukup untuk itu.

Suatu perjanjian harus dilaksanakan dengan etikat baik (Pasal 1338 ayat 3 B.W.). Sedangkan etikat baik menurut Jack Beatson and Daniel Friedmann:

Good faith means not only honesty in fact but also "the observance of reasonable standards of fair dealing in the trade. $^{43}$

Sedangkan R. Wiryono Prodjodikoro mengatakan sebagai berikut:

42 Sudargo Gautama, "Essay's in Indonesian Law", (Bandung: Citra Aditya Bhakti, 1991): hal. 191, bandingkan menurut Henry R.Cheeseman, elements of contract I e, agreement, consideration, contractual capacity, lawful object.

43 Jack Beatson and Daniel Friedmann, "Good Faith and Fault in Contract Law", (Oxford: Clarendon Press, tanpa tahun), hal. 154-155. 
Etikat baik tidak saja bekerja setelah perjanjian dibuat tetapi juga telah mulai bekerja sewaktu pihak-pihak memasuki perjanjian yang bersangkutan. ${ }^{44}$

Bandingkan dengan yurisprudensi Mahkamah Agung tanggal 2 Juni 1971 nomor 117 K/SIP/1971 Jo. Putusan Pengadilan Tinggi Bandung tanggal 23 Juli 1970 nomor 70/1969/PERD/PT.B yang isinya:

Kekuatan mengikat dari perjanjian adalah undang-undang dari kedua belah pihak.

Di dalam suatu kontrak terdapat setidak-tidaknya dua pihak atau lebih dan sudah pasti pihak-pihak yang mengikatkan dirinya dengan kontrak tersebut diharapkan akan terlaksana dan berhasil dengan baik sebab apabila kontrak tersebut tidak berhasil terlaksana dengan baik maka yang akan timbul suatu kegagalan

Force majeure seringkali menjadi konflik hukum dan sengketa antar pihak-pihak yang membuat kontrak perjanjian ${ }^{45}$ seperti para pihak pengusaha nasional dengan nasional maupun pengusaha lokal dengan nasional ataupun pengusaha nasional dengan internasional, baik di lingkungan kewenangan pengadilan Indonesia maupun pemilihan hukum dari suatu negara dan apabila ada pertikaian antara suatu negara dengan negara lain maka Pengadilan Internasional yang memutuskannya apabila ada konflik di bidang KUH Pidana maupun KUH Perdata.

Di dalam hukum perdata kita mengenal istilah perikatan dan bilamana di dalam perikatan ${ }^{46}$ ternyata salah satu pihak tidak memenuhi kewajiban ataupun prestasinya, maka disebut Wanprestasi, sedangkan apabila di dalam perikatan ternyata salah satu pihak tidak dapat memenuhi kewajibannya atau prestasinya bukan karena kesalahannya peristiwa yang terjadi di luar kehendaknya maka disebut force majeure dan hal ini sesuai dengan article 6:74, paragraph $1 .^{47}$ hal. 56-57.

${ }^{44}$ R. Wiryono Prodjodikoro, “Asas-asas Hukum Perdata”, (Bandung: PT. Balai, 1986),

${ }^{45}$ R. Subekti menyebutkan bahwa suatu perjanjian karena adanya kedua belah pihak sebagai untuk melakukan sesuatu, "Hukum Perjanjian:, (Jakarta: Internusa, 1985), hal. 1.

${ }^{46}$ Pitlo, Perikatan adalah suatu hubungan yang bersifat harta kekayaan antara dua orang atau lebih, atas dasar suatu pihak yang satu berhak (kreditur) dan pihak yang lain berkewajiban (debitur) atas suatu prestasi, Het Verbintenissenrecht naar het Nederlands Burgelijk Wetboek, (Tjeenk-Willink en Zoon, Haarlem,1952), hal. 2. bandingkan dengan GR. Van der Burght, perikatan adalah suatu hubungan hukum harta kekayaan antara dua orang atau lebih, yang menurut ketentuan seseorang atau lebih berhak atas sesuatu, sedangkan yang seorang lagi atau lebih berkewajiban untuk itu (oleh GR. Van der Burght Guru Besar Vrije Universiteid Kusterdeny), buku tentang perikatan dalam teori yurisprudensi berisi yurisprudensi Netherland sekitar perang dunia kedua, penyadur F. Tengker, editor, Willa Chandra serta Supriadi, (Bandung: Penerbit Mandar Maju 1999), hal. 1.

${ }^{47}$ Arthur S. Hartkamp, Op. Cit., hal. 120. 
Peristiwa yang terjadi dalam praktek perubahan kebijaksanaan pemerintah tidak jarang dimasukkan pula sebagai suatu Force majeure. Contoh: Ganti kerugian, prinsip ganti rugi dalam perjanjian selalu hadir dalam setiap sistim hukum. Setiap pihak yang dirugikan berhak untuk menuntut ganti rugi atas tidak dipenuhinya atau dilanggarnya atau diabaikannya suatu ketentuan dalam perjanjian oleh pihak lainnya.

Dalam rangka penelitian desertasi ini akan menjelaskan sebelumnya perihal overmacht dalam kasus pidana dan force majeure dalam kasus perdata juga itikad baik dari debitur, oleh karena itu tiap putusan hakim dan pertimbangan hukumnya haruslah mengandung arti tekstual dan konseptual.

Secara tekstual menurut Hakim dalam menegakkan keadilan ${ }^{48}$ berpedoman dari yang diatur dalam hukum padahal dalam menegakkan keadilan seharusnya bukan hanya ditentukan secara tekstual saja tapi juga kontekstual, artinya hakim juga harus mencermati pandangan dari masyarakat. Memang tidak lazim untuk menerapkan pola seperti itu, tapi bila ada kemauan untuk menjadikan putusan Pengadilan bersifat obyektif tidak hanya pengambilan putusannya saja yang terbuka tetapi termasuk juga proses musyawarah sebelum putusan itu dijatuhkan di meja hijau.

Metode penemuan hukum oleh hakim terdapat perbedaan: Pandangan tentang metode atau cara penemuan hukum oleh hakim menurut ahli hukum dari Civil Law dengan ahli hukum yang berasal dari Sistem Hukum Common Law. Pada umumnya ahli hukum Civil Law, tidak memisahkan secara tegas antara metode interpretasi dengan metode konstruksi dapat dilihat pada buku-buku karangan Paul Scholten, Pitlo ataupun Sudikno Mertokusumo di Indonesia. Sebaliknya banyak pengarang Common Law, misalnya L.B. Curzon, membuat pemisahan yang tegas antara metode interpretasi dengan metode konstruksi.

Michel van Kerckhove menyimpulkan doktrin "sensclair" terdiri dari 5 butir yaitu:

1. ada teks Undang Undang yang dimengerti maknanya sendiri dan berdasarkan setiap penjelasan sebelumnya serta tidak mungkin menimbulkan keraguan;

2. karena bahasa hukum berdasarkan pada bahasa percakapan seharihari maka dapat dianggap, semua istilah yang tidak ditentukan oleh pembuat Undang Undang tetap saja sama artinya dengan yang dimilikinya dalam bahasa percakapan biasa atau sehari-hari;

3. kekaburan suatu teks Undang Undang hanya mungkin terjadi karena mengandung kemenduaan arti (ambiguitas) atau karena kekurang tetapan arti yang lazim dari istilah-istilah itu;

48 Han's Kelsen, “What is Justice”, (Law and Practice in the Mirror of Science University, 1957), hal. 1, Justice is Primarely A Possible, But Not A Necessary, Quality of Sosial Order, Regulating Law Material Relation of Man. 
4. secara ideal, biasanya yang dijadikan pegangan bagi pembuat Undang Undang adalah ia harus merumuskan teks Undang Undangnya dengan sejelas-jelasnya. Kekaburan teks harus dihindari, demikian pula jangan sampai terjadi perumusan yang kurang baik; dan

5. untuk mengetahui adanya kekaburan ataupun tidak adanya kekaburan teks Undang Undang, tidak diperlukan penafsiran. Sebaliknya pengakuan tentang jelas atau kaburnya teks menghasilkan criteria yang memungkinkan untuk menilai apakah suatu penafsiran atau penemuan hukum memang atau tidak diperlukan, dan kalau diperlukan atau tidak diperlukan, hasilnya dalam penerapan hukum adalah sah. ${ }^{49}$

Senada dengan Anton $M$ Moeliono maka Bagir Manan ${ }^{50}$ mengemukakan pendapat bahwa dalam menyusun peraturan per-Undangundangan perlu diperhatikan hal-hal sebagai berikut:

Pertama, Kata atau ungkapan yang digunakan harus baku; kedua, Kata atau ungkapan harus digunakan secara konsisten; ketiga, Kata atau bahasa yang digunakan harus mudah dimengerti secara umum oleh masyarakat, tanpa mengurangi sifat kebakuan bahasa atau kata tertentu; keempat, Kata atau bahasa digunakan dalam satu arti, tidak boleh mengandung berbagai penafsiran atau pengertian; dan kelima, Susunan kalimat diupayakan sederhana dan pendek.

Kesulitan yang sering muncul adalah sehubungan adanya perubahan keadaan setelah ditandatanganinya perjanjian/kontrak tersebut. Kewajiban melaksanakan prestasi di dalam perjanjian banyak tidak dapat dipenuhi oleh debitur. Bagi debitur yang menutup perjanjian kredit dengan pihak kreditur dalam mata uang dollar Amerika dikaitkan dengan nilai tukar rupiah di dalam krisis ekonomi, dengan sendirinya hutang debitur menjadi bertambah besar dan beban hutang menjadi berlipat ganda besarnya dari jumlah nominal hutang mereka/debitur semula. ${ }^{51}$ (lihat Yurisprudensi Mahkamah Agung nomor $112 \mathrm{~K} / \mathrm{SIP} / 1963$ Jo. Nomor 74 K/SIP/1969 Jo. Nomor 380 K/SIP/1975 Jo. Nomor 736

\footnotetext{
${ }^{49}$ Achmad Ali, Op. Cit., hal. 145.
}

${ }^{50}$ Bagir Manan, Bahasa Hukum dan Peraturan Per-Undang-undangan Dalam Analisis dan Evaluasi Tentang Perkembangan 25 tahun Penggunaan Bahasa Hukum, BPPN, Departemen Kehakiman 1994/1995, hal. 29, dikutip dari "Majalah Hukum Nasional", Badan Pembinaan Hukum Nasional, Departemen Kehakiman Republik Indonesia nomor I/1999, hal. 5 .

${ }^{51}$ Menurut versi Far Eastern Economic Review, Februari 26 1998, Indonesia adalah lokasi investasi yang paling tidak menarik diantara Negara-negara ASEAN seperti Malaysia, Thailand, Korea Selatan dan Philipina, yang paling parah dilanda krisis. 
K/SIP/1972 Jo. Nomor 92 K/SIP/ 1952 Jo. Nomor 26 K/SIP/1955, yang intinya menyatakan sebagai berikut:

Bilamana terjadi perubahan nilai mata uang maka resikonya akan ditanggung bersama-sama rata seprauh-separuh antara debitur dan kreditur dengan menggunakan harga emas sebagai ukuran. ${ }^{52}$

Proses akhir ini menjadi bagian the binding force of precedent atau gezag van gewijsde, yang dinamakan kekuatan mengikat suatu putusan hakim $^{53}$. Kekuatan mengikat ini dapat tampil dalam fungsinya yang negatif: seseorang tidak dapat digugat untuk kedua kalinya mengenai perkara yang sama oleh pihak-pihak yang sama pula (ne bis in idem), lihat Yurisprudensi Mahkamah Agung tanggal 13 April 1976 nomor 647 K/SIP/1973 yang isinya berbunyi demikian:

Ada atau tidaknya azas nebis in idem tidak semata-mata ditentukan oleh para pihak saja, melainkan terutama bahwa objek dari sengketa sudah diberi status tertentu oleh keputusan Pengadilan Negeri yang lebih dahulu dan telah mempunyai kekuatan pasti dan alasannya adalah sama.

Di dalam hukum perdata tentang gezag van gewijsde suatu putusan hakim menjadi Rest judicata pro veritate habetur dalam arti (perkara perdata) apabila telah memperoleh kekuatan hukum yang pasti maka sekali diperoleh putusan tertutup kemungkinan bagi para pihak untuk penuntutan ulang berikutnya. Menurut Socrates:

Hakim harus mempunyai four things belong to a judge, 1. to hear courteously (mendengar dengan sopan,beradab); 2. to answer wisely (menjawab bijaksana,arif); 3. to consider soberly (mempertimbangkan tak berpengaruh); and 4. to decide impartially (memutus tak berat sebelah). ${ }^{54}$

Sebagai suatu hal yang sudah diterima oleh Hoge Raad di Negeri Belanda, namun hakim harus berpedoman bahwa semua perjanjian harus dilaksanakan dengan etikat baik, hakim berkuasa mencegah suatu pelaksanaan yang terlalu amat menyinggung rasa keadilan. ${ }^{55}$

${ }^{52}$ Rangkuman Yrusidprudensi Mahkamah Agung Republik Indonesia cetakan kedua tahun 1953.

${ }^{53}$ Sebagaimana kita ketahui, putusan Hakim juga memiliki factual effect, evidentiary effect serta executing effect. hal 163 .

${ }^{54}$ B. James; Handbook of Quotation S.S Mulbaruh \& Brother PTE, LTD, (Singapore)

55 R.Subekti, Op. Cit., hal. 41-43, bandingkan dengan pendapat .. Justice is a noun (mass noun) just behaviour or treatment for instance a concern for justice, peace, and genuine respect for people or the quality of being fair and reasonable. 
Keputusan Mahkamah Agung itu merupakan tugas menegakkan hukum dan keadilan berdasarkan Pancasila dengan jalan menafsirkan hukum dan mencari dasar-dasar serta asas-asas yang menjadi landasannya sehingga putusan itu mencerminkan perasaan keadilan bangsa dan rakyat Indonesia. ${ }^{56}$

Menelusuri asal mula perjanjian, sejak jaman dahulu di dunia perdagangan antara pedagang yang satu dengan pedagang yang lainnya saling percaya dan mempercayai dan selalu menjunjung tinggi asas kebebasan berkontrak asas kepercayaan dan kejujuran serta etika bisnis sehingga Henry Ford berpendapat:

Someday the ethics of business will be universally recognized and in that day business will be seen to be oldest and most useful of all the profession. ${ }^{57}$

Pendapat tersebut diatas dilengkapi pokok pikiran Treitel:

Asas kebebasan berkontrak dapat digunakan untuk merujuk kepada dua asas umum. Asas umum yang pertama menentukan bahwa hukum tidak membatasi syarat-syarat yang boleh dibuat oleh para pihak. Asas tersebut tidak membebaskan berlakunya syarat-syarat suatu perjanjian. Hanya karena syarat-syarat suatu perjanjian tersebut kejam atau tidak adil bagi suatu pihak. Asas kedua menentukan bahwa pada umumnya seseorang menurut hukum tidak dapat dipaksa untuk memasuki suatu perjanjian. ${ }^{58}$

Dengan alasan Force majeure dapat mengakibatkan salah satu pihak di dalam perjanjian tidak melakukan kewajibannya dalam hal ini sangatlah merugikan pihak lainnya. Apabila terjadi kasus Force majeure peranan hakim sangatlah menentukan sebab sampai saat ini pendapat hakim tentang keadaan dalam krisis ekonomi selalu berbeda pendapat seperti yang dituangkan dalam Yurisprudensi Mahkamah Agung Republik Indonesia tanggal 27 April 1955 nomor $92 \mathrm{~K} / \mathrm{SIP} / 1955 .^{59}$

6 Sudikno Mertokusumo, "Menganut Hukum Suatu Pajak", (Yogyakarta: Liberty, 1999), hal. 128.

${ }^{57}$ B. James, Op. Cit., hal 36.

58 GH.Treitel, "An outline of The Law of Contract", fouth edition, (London: Butterworth, 1989), hal. 2-4.

${ }^{59}$ Lihat Ridwan Syarani, "Seluk Beluk dan Asas Hukum Perdata", (Bandung: Alumni 1992), hal. 263-264, lihat juga Subekti, "Hukum Perjanjian", Op. Cit., hal. 43. 
Perbedaan dasar dan landasan hukum bagi hakim yang satu belum tentu sama dengan hakim lainnya, sehingga akan mendapatkan penemuan hukum yang baru (Rechvinding). ${ }^{60}$

Menurut asas umum: Setiap kelalaian dan keingkaran mengakibatkan si pelaku wajib mengganti kerugian serta memikul segala risiko kelalaian dan keingkaran tersebut, sebagaimana ditemukan di dalam Pasal 1243 B.W.. Akan tetapi jika pelaksanaan pemenuhan perjanjian yang menimbulkan kerugian terjadi karena keadaan memaksa, debitur dibebaskan menanggung kerugian yang terjadi.

Kerugian terjadi semata-mata oleh keadaan atau peristiwa di luar kemampuan perhitungan debitur, berarti keadaan dari peristiwa tadi menjadi dasar hukum yang melepaskan debitur dari kewajiban mengganti kerugian, dengan kata lain debitur bebas dari kewajiban membayar ganti rugi apabila dia berada dalam force majeure yang menyebabkan menghalangi debitur melaksanakan pemenuhan prestasinya.

Lingkup penelitian menyangkut hukum dari Pasal 1244 B.W. sebagai salah satu Pasal yang menyingkirkan ketentuan Pasal 1239 B.W. tersebut. $^{61}$ Pasal 1244 B.W. telah merumuskan debitur yang terlambat atau lalai melaksanakan kewajiban prestasi yang diperjanjikan dan hal ini menimbulkan kerugian kepada pihak kreditur, tidak diwajibkan debitur membayar untuk mengganti kerugian jika ia dapat membuktikan bahwa terjadi di luar kesalahannya, yang semata-mata oleh sebab keadaan yang datang di luar perhitungannya dalam arti terjadi overmacht.

\section{Perbandingan Pertimbangan Hakim Civil Law dan Common Law}

\section{Hukum Pidana Civil Law}

Pertimbangan hukum bagi negara Civil Law di dalam menjatuhkan pidana overmacht sangat hati-hati karena pasal-pasal yang banyak digunakan bukannya Pasal 48 KUHP melainkan Pasal 49 ayat 1 KUHP atau Pasal 49 ayat $2 \mathrm{KUHP}$. Lihat perkara nomor 395/K/Pid/1999 Jo. Nomor 513/Pid/B/1998/PN PLG, atas nama M. Akibsyah bin Hasan, bandingkan pula dengan perkara nomor 225/Pts/Pid/B/1997/PN PLG atas nama terdakwa Muhammad Alferi bin Bakaruddin Paris, lihat pula

60 Sudikno Mertokusumo, "Penemuan Hukum Sebuah Pengantar", (Yogyakarta: Liberty, 1996), hal. 1, yang menyebutkan: Penemuan hukum bukanlah merupakan ilmu baru tetapi telah lama dikenal dan dipraktekkan selama ini oleh Hakim, Pembentuk Undang-undang antara Sarjana Hukum yang tugasnya memecahkan masalah-masalah hukum.

${ }^{61}$ Bunyi Pasal 1239 B.W.: Tiap-tiap perikatan untuk berbuat sesuatu, atau untuk tidak berbuat sesuatu, apabila Si berutang tidak memenuhi kewajibannya mendapatkan penyelesaiannya dalam kewajiban memberikan penggantian biaya rugi dan bunga. 
perkara nomor $525 \mathrm{~K} / \mathrm{Pid} / 1991$ Jo. Nomor 262/Pts/Pid/B/1990/PN LLG atas nama terdakwa Tarigan bin Satar.

Sedangkan negara Common Law di dalam menjatuhkan putusan tentang self defense lebih gampang dan lebih simple sehingga banyak perkara pidana yang dikaitkan dengan self-defense.

\section{Hukum Pidana Common Law}

Lihat perkara Wilson v United States 198 F 2d 299/91 US APP DC.135-1952 tentang self defense, begitu gampangnya hakim menyatakan self defense terhadap terdakwa yang diserang oleh segerombolan pria dan wanita pengacau, kemudian terdakwa menembaknya dengan alasan membela diri.

Bandingkan perkara Silas v Bowen, 277 F SUPP 314/SC/1967, dimana terdakwa Silas yang badannya kecil ketika dianiaya oleh orang yang bertubuh besar, langsung menembak dengan alasan membela diri.

Bandingkan pula perkara Burdon v Wood 142 F 2d 303/Ind/1944 dimana pemilik bar yang diserang secara mendadak oleh Burdon dan pemilik bar menembak Burdon hingga dapat dikategorikan sebagai self defense.

\section{Hukum Perdata Civil Law}

Lihat perkara nomor 26/Pdt/G/1996/PN PLG atas nama CV. Thamrin Brothers terbakarnya mobil yang dibeli secara sewa beli adalah merupakan force majeure (Pasal 1444 B.W.)

Bandingkan pula perkara nomor 16/Pdt/G/1988/PN PLG atas nama Tan Guan Beng yang intinya perubahan nilai mata uang dianggap force majeure.

Lihat pula perkara nomor 463/Pdt/G/1997/PN JKT BAR, keterlambatan izin dari pemerintah (Gubernur) adalah merupakan relatief force majeure.

\section{Hukum Perdata Common Law}

Lihat kasus The Neptune Agate' et al; Zenith Taiwan Corp \& Ors v Owners of and other persons interested in the ships or Vessels 'Neptune Agate'et al High Court - Admiralty in Rem Nomor 196 of 1988 Warren LH Khoo J 19-22 July 1993, 19 August 1994, force majeure yang terjadi disebabkan oleh act of God yaitu banjir.

Bandingkan dengan kasus Dunlop vs Lambert (1839) 6 Cl \& Fan 600 ZER 824 (failed), yang menyebutkan typhoon adalah force majeure oleh act of God.

Negara Civil Law di dalam perkara pidana hanya mengenal keadaan memaksa sebagaimana Pasal 48 KUHP dan para hakim sangat jarang mempergunakan pasal ini melainkan Pasal 49 ayat 1 KUHP ataupun Pasal 49 ayat 2 KUHP. 
Negara Common Law di dalam perkara pidana mengenal 18 macam self defense dan karena menganut asas The Binding Force of Precedent maka para hakim di dalam mengadili perkara pidana lebih gampang mengaitkan pasal-pasal di dalam self defense tersebut.

Negara Civil Law di dalam perkara perdata hanya mengenal Pasal 1244 B.W. dan Pasal 1245 B.W. terhadap force majeure dan berkaitan dengan Pasal 1444 B.W. dan Pasal 1445 B.W. Tetapi negara Common Law mengenal 16 macam force majeure.

Oleh karena itu para hakim di negara Common Law mempunyai wawasan lebih baik, lebih luas daripada hakim di negara Civil Law.

\section{Penutup}

\section{Kesimpulan}

Dari hasil penelitian yang telah diuraikan dalam bab-bab terdahulu, maka dapat dikemukakan kesimpulan-kesimpulan sebagai berikut:

1.a. Pertama, pertimbangan hakim dari negara yang menganut system Civil Law di dalam menjatuhkan putusan yang berhubungan dengan overmacht adalah sangat sulit, di mana hakim lebih banyak menggunakan Pasal 49 KUHP dibandingkan overmacht itu sendiri yaitu Pasal 48 KUHP, sedangkan di dalam negara yang menganut system Common Law hakim lebih gampang menjatuhkan putusan melepaskan terdakwa dari segala tuduhan dan tuntutan hukum karena adanya self defense ataupun ke-18 macam defenses. Selanjutnya pertimbangan hakim dari system Civil Law dalam menjatuhkan putusan yang berhubungan dengan force majeure hanya ada dua saja yaitu force majeure yang absolute dan force majeure yang relatif yang berhubungan dengan Pasal 1244 B.W. dan Pasal 1245 B.W serta Pasal 1444 B.W. dan Pasal 1445 B.W. Sedangkan di negara yang menganut system Common Law dalam menjatuhkan putusan yang berhubungan dengan force majeure digunakan pasal-pasal sebanyak 16 macam force majeure.

1.b. Ketiga, pertimbangan hakim dari Mahkamah Agung Republik Indonesia Jo. Pengadilan Tingi Jo. Pengadilan Negeri terhadap overmacht yang terdapat di dalam Pasal 48 KUHP jarang diterapkan di dalam putusan-putusan perkara pidana, dan kebanyakan putusan hakim dari Mahkamah Agung Republik Indonesia Jo. Pengadilan Tinggi Jo. Pengadilan Negeri tidak menerapkan pasal ini dan yang lebih dominan para hakim mempergunakan Pasal 49 KUHP dibandingkan dengan Pasal 48 KUHP. Sedangkan pada negaranegara Common Law mereka mempergunakan overmacht yang telah disebutkan di depan yaitu yang terdapat di dalam defenses berjumlah 18 macam pada negara Civil Law hanya menganut 2 macam. 
1.c. Keempat, pertimbangan hakim dari Mahkamah Agung Republik Indonesia Jo. Pengadilan Tinggi Jo. Pengadilan Negeri di negaranegara Civil Law dalam menjatuhkan putusan dalam perkara overmacht dapat menggunakan doktrin Sens Clair yang memungkinkan seorang hakim untuk menemukan hukum (Rechvinding) yang disimpulkan oleh Michel Van Kerckhove. Sedangkan pertimbangan hakim pada negara-negara Common Law dalam menjatuhkan putusan dalam perkara overmacht mereka menganut asas The Binding Force of Precedent yaitu hakim pada tingkat rendah harus mengikuti dan patuh pada putusan hakim yang lebih tinggi sebelumnya.

1.d. Kelima, pertimbangan hakim dalam negara Common Law lebih simple dan praktis menggunakan pasal-pasal di dalam self-defense dan begitu gampangnya hakim menerapkan pasal-pasal self-defense tersebut sekalipun orangnya tidak sampai mati tetapi pada system Civil Law seperti negara kita Indonesia, overmacht maupun noodweer sangat jarang sekali diterapkan oleh para hakim di dalam memutuskan perkara pidana, dengan demikian persamaan overmacht dalam negara yang menganut system Civil Law dan Common Law adalah tersangkanya sama-sama dilepaskan dari segala tuduhan dan tuntutan hukum sedangkan perbedaannya adalah sebagaimana yang disebutkan di atas yakni hakim dalam negara-negara yang menganut system Common Law lebih mudah memasukkan dalam pertimbangan hukumnya tentang overmacht dibandingkan dengan negara yang menganut system Civil Law.

1.e. Keenam, pertimbangan hakim dari Mahkamah Agung Republik Indonesia Jo. Pengadilan Tinggi Jo. Pengadilan Negeri tentang force majeure dalam negara yang menganut system Civil Law /B.W. hanyalah terdapat di dalam Pasal 1244 B.W. dan Pasal 1245 B.W. jadi menurut penulis terlalu minim di dalam perjanjian hukum kontrak yang menyangkut masalah Force majeure haruslah dicantumkan secara tegas dan nyata kemungkinan-kemungkinan yang terjadi sehingga menyebabkan kegagalan terjadi di dalam kontrak tersebut. Sedangkan pada negara Common Law mereka telah mempersiapkan 16 macam force majeure yang telah menjadi hukum yang tetap dan harus dipatuhi di dalam negara tersebut.

1.f. Kedelapan, pertimbangan hakim dari Supreme Court of Singapore terhadap force majeure di negara-negara yang menganut sistem Common Law jauh lebih lengkap dibandingkan dengan B.W. karena mereka telah mengenal 16 macam force majeure sebagaimana yang telah diuraikan di muka dan B.W. hanya mengenal dua macam.

2.a. Kedua, persamaan overmacht di dalam negara yang menganut system Civil Law dan Common Law adalah adanya suatu daya paksa yang telah memaksa kepada si terdakwa sehingga terdakwa terpaksa melakukan tindak pidana demi untuk membela diri, membela 
kehormatan, nyawa ataupun harta bendanya. Sedangkan perbedaannya adalah negara-negara yang menganut system Common Law lebih gampang memakai pasal overmacht ini dibandingkan dengan negara-negara yang menganut system Civil Law sebab hakim di negara-negara Common Law telah mempunyai wawasan yang luas sekali dan didukung dengan pasal-pasal yang tersedia.

Perbedaan force majeure di dalam negara yang menganut Civil Law dan Common Law adalah di negara Civil Law hanya mengenal dua macam force majeure yaitu force majeure yang absolut dan force majeure yang relatif sedangkan di negara-negara Common Law mereka telah mengenal 16 macam force majeure, yang dapat ditarik dari putusan dari negara Civil Law dan Common Law adalah negara Civil Law haruslah mengembangkan dan/atau mengikuti perkembangan hukum sehingga dapat sama pula dengan negaranegara Common Law.

2.b. Ketujuh, di dalam memutuskan perkara Force majeure maka hakim seharusnya lebih meneliti tentang kontrak yang ada diantara kedua belah pihak lebih teliti, lebih jeli dan lebih akurat dibandingkan selama ini. Dengan adanya tulisan ini maka akan menambah wawasan hakim untuk mengetahui dan atau setidak-tidaknya mempelajari lebih dalam dan lebih jauh terhadap Force majeure paling tidak lebih tahu dan semula yang hanya mengenal Absolute Force majeure dan Relative Force majeure saja.

2.c. Kesembilan, system hukum menurut Civil Law tidaklah mengacu kepada yurisprudensi sedangkan system hukum negara Common Law mengacu pada yurisprudensi maka disebut the binding force of precedence dan haruslah menjadi star desisis sebagaimana yang terjadi di negara-negara seperti Singapore, Melbourne dan Sidney. Hakim harus berani menentukan di dalam putusannya apakah suatu force majeure termasuk dalam Absolute Force majeure, Relative Force majeure, Impossibility Force majeure, Impracticability Force majeure, frustration Force majeure, Temporary Force majeure, Permanent Force majeure, hardship.

\section{Saran}

Pertama, dalam KUHP hendaknya ditambah dan diperluas pengertian dari pembelaan dimana selama ini KUHP hanya mengenal dua macam overmacht saja. Oleh karena itu sekalipun sistim hukum Indonesia yang menganut Civil Law dan Singapore yang menganut Common Law tetapi norma ataupun norma hukum yang lebih baik dari Common Law Singapore dapat juga dikembangkan dalam KUHP Indonesia.

Kedua, pertimbangan hukum yang ditemukan oleh hakim yang memutuskan perkara keadaan memaksa lebih condong mengalihkannya kepada noodweer dan/atau noodweerexces, jadi ada indikasi hakim kurang menguasai dan mengerti lebih jauh tentang overmacht. 
Ketiga, adapun peningkatan sumber daya manusia yakni pendidikan berkala bagi para penegak hukum agar tidak ketinggalan dan mengetahui akan perkembangan hukum.

Keempat, dalam B.W. yang selama ini hanya mengenal absolute force majeure dan relative force majeure hendaklah dikembangkan menurut kebutuhan yang sudah sangat mendesak agar dapat menyamakan Civil Law dengan Common Law.

Kelima, adapun bahasa hukum yang tegas, jelas di dalam kontrak sehingga tidak dapat ditafsirkan lain oleh para pihak maupun oleh hakim di Pengadilan Negeri.

Keenam, meningkatkan moral maupun budi pekerti yang ada pada para penegak hukum sehingga supremasi hukum dapat ditegakkan dengan cara memberikan imbalan jasa / gaji yang memadai sehingga tidak ada Kolusi Korupsi dan Nepotisme (KKN) dari para penegak hukum itu sendiri dan mengadakan pembersihan pada jajaran penegak hukum masing-masing.

Ketujuh, harus berani membuat terobosan baru apabila hakim memutuskan perkara baik pidana maupun perdata yang menyimpang dari teori hukum berdasarkan bukti, saksi yang ada serta kenyataan yang sebenarnya maka hakim yang bersangkutan dapat dipidana atau setidaktidaknya diproses/diperiksa oleh pemeriksa ad hoc, demikian juga harus diterapkan kepada Jaksa Penuntut Umum ataupun polisi yang berbuat sama.

Kedelapan, apabila terjadi force majeure dalam kasus perdata sudah pasti ada pihak yang dirugikan, sekalipun ia mengajukan gugatan melalui Pengadilan Negeri sebagai penggugat maka tergugat dapat menangkis dengan alasan force majeure oleh karena itu siapa yang harus menanggung beban kerugian tersebut? sebab apabila diasuransikan maka beban ada di tangan asuransi tetapi apabila barang-barang tersebut tidak diasuransikan maka untuk melindungi kepentingan dari pihak yang dirugikan setidak-tidaknya ada satu lembaga baru dari pemerintah guna mengatasi masalah demikian. 


\section{Daftar Pustaka}

Ali, Achmad. Menguak Tabir Hukum, Suatu Kajian Filosofis dan Sosiologis, Jakarta Penerbit: Toko Gunung Agung, 2002.

Arie, S. Sundari. Majalah Hukum Nasional, Badan Pembinaan Hukum Nasional, Departemen Kehakiman nomor 2/2002 Dalam Artikel "Transaksi Kredit".

Boggiano, Antonio. International Standard Contracts, The Price of Fairness, tanpa kota: tanpa penerbit, 1991.

Cheeseman, H.R. Contemporary Business Law, second edition, London: Prentice Hall, 1997.

Cormack, M.H.MC. Why They Didn't Teach Me At Yale Law School, Fontana/Collen 1987.

Curzon, L.B, Dictionary of Law, Fourth Edition, Pitman Pusblishing Universal Book Traders, 1995.

Dune, JV, diterjemahkan oleh Lely Niwan, Wanprestasi dan Keadaan Memaksa, Ganti Kerugian, Yogyakarta 29 Agustus - 09 September 1988.

Gautama, S. Essay's in Indonesian Law, Bandung: P.T. Citra Aditya Bhakti, 1991.

. The Commercial Laws of Indonesia, Bandung: Citra Aditya Bakti, 1998.

Bhakti, 1995.

Garner, B.A, Editor In Chief, Black's Law Dictionary, seventh edition, ST Paul-MINN, West Group, 1999.

Hakim Alamsyah \& Bambang Pramono. Laporan Workshop, "The Credit Crunch in East Asia, What Do We Know? What Do We Need Know?" World Bank Washington, DC, 30 November-1 Desember 1999, dalam Majalah Hukum Nasional, Badan Pembinaan Hukum Nasional, Departemen Kehakiman Republik Indonesia nomor 2, 2002.

Harahap, M.Y, Hakim Agung di Mahkamah Agung, Segi-segi Hukum Perjanjian, Bandung: Alumni, 1986.

Hartkamp, A.S, Contract Law in The Netherlands, Kluwer Law Internasional The Hague-London-Boston 1995.

Hartono, Sunarjati. Hukum Ekonomi Pembangunan Indonesia, Bandung: Penerbit Alumni, 1988.

Juwana, Hikmahanto. Bunga rampai Hukum Ekonomi dan Hukum Internasional, cetakan I, Jakarta: Lentera Hati, 2002. 
James, B. Handbook of Quotation, Singapore: S.S Mulbaruh \& Brother PTE, LTD, tanpa tahun.

Kian, C.T.S. Contract Law, A Layman's Guide, Times Books International, Singapore-Kuala Lumpur, 2000.

Kelsen, Hans. What is Justice, Law and Practice in the Mirror of Science University of California and Los Angeles 1957.

Lubis Sentosa, Maulana. Sriro's Reference an Indonesian Arbitratio Law, Jakarta: Penerbit Perpustakaan Nasional Katalog, 2000.

Lumintang, PAF. Dasar-dasar Hukum Pidana Indonesia, tanpa kota: tanpa penerbit, 1997.

Mertokusumo, Sudikno. Penemuan Hukum Sebuah Pengantar, Yogyakarta: Liberty 1996.

. Menganut Hukum Suatu Pajak, Yogyakarta: Liberty, 1999.

. Mengenal Hukum, Yogyakarta, Penerbit Liberty, 1999

Pompe, S, Indonesian Law 1949-1989, A Bibliography of ForeignLanguage Materials With Brief Commentaries on The Law, Martinus Nijhoff Publishers, Dordrecht-Boston-London, 1992.

Pound, Roscoe, The Spirit of The Common Law, with a new introduction by Neil Hamilton \& Mathias Alfred Jaren, Transaction Publishers, 1998.

Subekti R. Hukum Perjanjian, Jakarta: Inter Nusa, 1985. . Aneka Perjanjian, Bandung: P.T. Citra Aditya Bakti, 1995. . Pengertian Perjanjian Sewa Menyewa, Jakarta: P.T. Pradnya Paramita, 1989.

Syarani, Ridwan. Seluk beluk dan Asas Hukum Perdata, Bandung: Alumni, 1992.

Treitel, G.H. An outline of The Law of Contract, fouth edition, London, Butterworth, tanpa tahun.

Wilamarta, Misahardi. Hak Pemegang Saham Minoritas dalam rangka Good Corporate Government, Fakultas Hukum Universitas Indonesia, 2002.

Majalah Hukum, Varia Peradilan tahun VII nomor 74.

Majalah Hukum, Varia Peradilan tahun I nomor 7 - April 1986.

\section{Undang Undang Yang Dipergunakan}

Kitab Undang-Undang Perdata.

Kitab Undang-Undang Hukum Pidana. 


\section{Putusan Mahkamah Agung}

Putusan Mahkamah Agung Republik Indonesia Nomor $021 \mathrm{~K} / \mathrm{N} / 2002$ tanggal 05 Juli 2002 jo. Putusan Pengadilan Niaga pada Pengadilan Negeri Jakarta Pusat, tanggal 13 Juni 2002, Nomor 10/PAILIT/2002/PN.NIAGA.JKT.PST.

Putusan Mahkamah Agung Republik Indonesia nomor 972 K/PDT/2000 tanggal 26 Oktober 2001 jo. Putusan Pengadilan Tinggi DKI Jakarta nomor 470/PDT/1998/PT DKI tanggal 01 Oktober 1998 jo. Putusan Pengadilan Negeri Jakarta Barat nomor 463/PDT/G/1997/PN JKT BAR tanggal 09 Maret 1998.

Putusan Mahkamah Agung No. 864 K/SIP/1973 tanggal 13 May 1975.

\section{Majalah Internasional}

Supreme Court of Singapore, The Judicial Construction Of Force majeure Clauses, chapter 1.

Bussiness Law, The Principles and Cases, Third Edition, Cincinnati Ohio, 1993 chapter 4: 35.

H. Linches \& Co, V. Klegenbrerg (CCA. $\left.9^{\text {th }}\right) 23$ F 2D 611: 35. 